\title{
Pattern of Traumatic Brain Injury at King Abdulaziz University Hospital
}

\author{
Mohammed Bangash, MD, FRCSC and Ahmad T. Alshareef ${ }^{\mathbf{1}}$ \\ Department of Surgery, Division of Neurological Surgery \\ and ${ }^{1}$ Medical Intern, Department of Surgery \\ Faculty of Medicine, King Abdulaziz University \\ Jeddah, Saudi Arabia \\ mhbangash@hotmail.com
}

\begin{abstract}
Traumatic brain injury is a common problem in society leading to morbidity and mortality. This study describes pattern of traumatic brain injury at King Abdulaziz University Hospital, and identify the demographic and clinical factors affected in the survivors' hospital length of stay. A retrospective study performed in January 2003 till January 2009. The incidence of traumatic brain injury requiring admission in relation to annual emergency room is $75 / 100,000$ patients; mean age is $9.5 \pm 4$ years with $\sim 81 \%$ of injuries occurring at $<30$ years. Severe traumatic brain injury accounts for $15.1 \%$ of cases, whereas moderate traumatic brain injury accounts for $10.4 \%$ and mild traumatic brain injury accounts for $74.5 \%$. Mechanisms of injuries: $46.5 \%$, falling from a height, $26.7 \%$ motor vehicle collisions, $10.4 \%$ pedestrian-vehicle collisions and $10.4 \%$ assault victims. Factors affecting the hospital length of stay: Admission Glasgow Coma Scale $(p<0.001)$, loss of consciousness $p<0.001$, presence of motor weakness $\mathrm{p}<0.001$, female gender $\mathrm{p}<0.03$, patients' age $\mathrm{p}<0.001$ and the nationality $\mathrm{p}<0.001$. Characteristics of traumatic brain injury: Young age, the mechanism of injury (mainly falls) and type of injury (mainly concussion). Tentatively, the patients' length of stay is predicted on the demographic and clinical data.
\end{abstract}

Keywords: Brain injury, Jeddah, Length of stay, Trauma centre.

Correspondence \& reprint request to: $\quad$ Dr. Mohammed Bangash

P.O. Box 42806, Jeddah 21551, Saudi Arabia

Accepted for publication: 15 December 2013. Received: 24 May 2013. 


\section{Introduction}

Traumatic brain injury (TBI) is a fairly common problem in Saudi Arabia and has a significant impact on victims, caregivers and the health care system. Eighty-one percent of deaths in Ministry of Health hospitals are due to road traffic accidents ${ }^{[1]}$ with a TBI mortality of $17.4 \%$. Head and facial injury account for $30 \%$ of all injuries and the cause $26 \%$ of recorded deaths ${ }^{[2]}$.

King Abdulaziz University Hospital (KAUH) is not a welldefined trauma referral centre according to the American College of Surgeons Trauma Centres ranks; however, TBI is not uncommon in the KAUH emergency room (ER). As inter-hospital referral is not well established, occasionally, patients with TBI receive treatment at the current study's institution. The TBI patients' length of stay (LOS) in the hospital sometimes becomes longer than expected which can affect the acute bed utilization, and increases the burden on the health care system.

The aim of this study is to describe the pattern of TBI at KAUH, and identify the factors affecting the hospital LOS for the TBI survivors.

\section{Methods}

This retrospective study based on all patients with TBI who required admission was included in the study. Medical files were reviewed for total number of patients with TBI and their ages, nationalities, neurological presentation, severity, costs and outcomes of TBI between January 2003 and January 2009. All patients at KAUH who required admission to the hospital had a CT scan at least once. The CT scans were reported by a neuroradiologist.

A total of 315 files were reviewed; 57 files were excluded, and 258 were included in the study. The excluded files were files related to patients without TBI, but suffered relatively other trauma (such as facial, ENT, and neck injuries). The incidence of TBI requiring admission in relation to annual ER visits $(343,158$ patients regardless of diagnosis) was 75/100,000 patients. All collected data were 
processed using SPSS 16 software (SPSS Inc., Chicago, Illinois, USA Version 16). The data were summarized as the mean \pm standard deviation, unless otherwise indicated. Univariate analysis of pooled data was performed with the "student's" $t$-test and Wilcoxon ranksum (Mann-Whitney test) for continuous parametric and nonparametric variables, respectively, and the $\chi^{2}$ test (or Fisher exact test) for categorical variables. The correlation was made between ages, clinical presentation, LOS using Spearman's rank correlation test. Cubic and quadratic regression tests were used for the multivariate analyses. Patients that expired or left the hospital against medical advice were excluded from the LOS analysis; differences with $p<0.05$ were considered significant.

The Ethics Committee of KAUH, Jeddah, Saudi Arabia approved this retrospective study without requiring patients' consent.

\section{Results}

\section{Patient Demographics}

The patient age distribution is given in Table 1. The mean age of patients with TBI was 9.5 years $(\mathrm{SD}=4)$. Around $81 \%$ of TBI occurred at an age $<30$ years, and $50 \%$ at an age $<10$ years.

Traumatic brain injury was more common in males $186(72 \%)$ than in females $72(28 \%)$, with a ratio of $2.5: 1$. The most common nationality involved in head injury was Saudis 147 (57\%), followed by Yemenis $27(10.4 \%)$ and Pakistanis $24(9.3 \%)$.

\section{Mode of Transportation}

Review of patient files indicated that 192 (75\%) patients were brought to the ER by civil cars, and $72(25 \%)$ were brought by ambulance. 


\section{Distribution of TBI by Year and Month and Mechanism of Injury}

The highest numbers of patients with TBI were treated in 2008 $(30.2 \%)$ and 2007 (21\%). By month, the highest numbers of patients were seen in February (19.7\%) and September (18.6\%).

Table 1. Patient age distribution.

\begin{tabular}{c|c|c|c|c}
\hline Age (Years) & Relative FQ & $\mathbf{\%}$ & Frequency & $\mathbf{\%}$ \\
\hline $0-9.9$ & 129 & 50 & 129 & 52 \\
\hline $10-19.9$ & 177 & 69 & 48 & 19 \\
\hline $20-29.9$ & 210 & 81 & 33 & 13 \\
\hline $30-39.9$ & 225 & 87 & 15 & 6 \\
\hline $40-49.9$ & 237 & 92 & 12 & 5 \\
\hline $50-59.9$ & 237 & 92 & 0 & 0 \\
\hline $60-69.9$ & 246 & 95 & 9 & 4 \\
\hline $70-79.9$ & 252 & 98 & 6 & 2 \\
\hline $80-89.9$ & 258 & 100 & 6 & 2 \\
\hline
\end{tabular}

Patients with TBI experienced trauma from a wide range of mechanisms, as follows: 120 (46.5\%) falling from a height; 69 (26.7\%), motor vehicle collisions, $27(10.4 \%)$ pedestrian-vehicle collisions; and $27(10.4 \%)$ assault victims. Of the motor vehicle collision victims, $78 \%$ were vehicle passengers and $22 \%$ were drivers, both with undocumented seat belt status.

\section{Severity and Type of Injury}

Injury severity was decided according to the Glasgow Coma Scale (GCS), with severe head injury scoring $<8$, moderate scoring 9-12 and mild scoring 13-15. Severe TBI accounted for 39 (15.1\%) of injuries (all had clinical and CT evidence of diffuse axonal injury), moderate TBI was $27(10.4 \%)$ of injuries and mild TBI was 192 $(74.5 \%)$ of injuries. There was some correlation between the severity of TBI and the nationality of the patients, where the African nationalities (Sudan, Somali, Ethiopia and Chad) tended to suffer from severer TBI than other patients $r(170)=0.04, \mathrm{p}<0.05$. 
The most common type of head injury was concussion 108 (35.29\%), followed by subdural hematoma $57(18.63 \%)$, cerebral contusion 45 (14.71\%) and epidural hematoma 39 (12.75\%) (Table 2). Among skull fractures, 114 (44\%) were linear skull fractures, of which $75(65.7 \%)$ were closed and $39(34.2 \%)$ were open, and 33 $(12.7 \%)$ were depressed skull fractures, of which $12(36.36 \%)$ were closed and $21(63.63 \%)$ were open; $111(42.49 \%)$ of patients had no skull fracture.

Table 2. Injury types.

\begin{tabular}{l|c|c}
\hline \multicolumn{1}{c|}{ Type of Injury } & Count & \% \\
\hline Concussion & 108 & 35.29 \\
\hline Contusion* & 45 & 14.71 \\
\hline Epidural Hematoma & 39 & 12.75 \\
\hline Intracerebral Hemorrhage* & 3 & 0.98 \\
\hline Intraventricular Hematoma* & 12 & 3.92 \\
\hline Penetrating Injury & 3 & 0.98 \\
\hline Subarachnoid Hemorrhage & 6 & 1.96 \\
\hline Subdural Hematoma* & 57 & 18.63 \\
\hline Subgalial Hematoma & 33 & 10.78 \\
\hline Total & $\mathbf{3 0 6}$ & $\mathbf{1 0 0 . 0 0}$ \\
\hline
\end{tabular}

*Patients had diffuse axonal injury in addition to the described injury: 19 with contusion, 12 with subdural hematoma, 7 with intra-ventricular haemorrhage and 1 with intra-cerebral haemorrhage

\section{Neurological Presentation}

The most common symptom in patients with TBI who required admission was reported on loss of consciousness (LOC) $126(48.8 \%)$ with a mean duration of $8.6 \mathrm{~min}$. The LOC duration was correlating significantly with the patients' age $r(256)=0.33, \mathrm{p}<0.001$. The next common symptom was nausea and vomiting 93 (36\%). However, the most common sign in patients with TBI who required admission based on confusion $120(47.5 \%)$, followed by motor weakness 42 $(16.2 \%)$.

\section{ICU Admission, Length of Stay and Outcome}

The number of patients who required an Intensive Care Unit (ICU) admission was 48 (18.6\%). A total of 57 (22.1\%) patients 
required surgical intervention. The mean length of hospital stay was 11.75 days; $156(60.4 \%)$ of patients left the hospital within 5 days. The average cost per patient was 37,224 SAR $(\approx \mathrm{US} \$ 10,000)$; the cost was estimated according to the price list of the KAUH private section.

Improvement was considered on any patient gained two or more points on GCS and/ or discharged from the hospital in independent state. Most of the patients improved 234 (90.6\%). There were 9 (3.5\%) disabled patients, $3(1 \%)$ patient expired and $12(4.6 \%)$ patients left the hospital against medical advice.

\section{Factors Affecting the Length of Stay in the Hospital:}

- Admission GCS: Patients with GCS between 6 and 11 tended to stay more than 10 days in the hospital $R^{2}=0.16, F(2,171)=16.9$, $\mathrm{p}<0.001$.

- Loss of consciousness (LOC) duration was significant factor affecting the length of stay in the hospital. Patients with LOC more than 22 minutes tended to stay more than 7 days in the hospital $r$ $(241)=0.25, \mathrm{p}<0.001$. (Fig. 1)

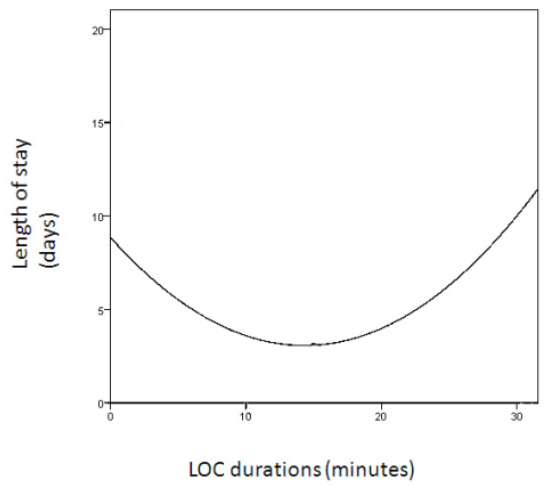

Fig. 1. Regression analysis curve shows the relationship between loss of consciousness (LOC) and length of stay.

- Confusion was not a significant factor to affect the length of stay in the hospital; $\mathrm{r}(241)=0.044, \mathrm{p}<0.49$. 
- Presence of motor weakness was a significant factor affected the length of stay of the patients in the hospital; $r(241)=0.38, p<$ 0.001

- ICU admission was a significant factor prolonged the patients stay in the hospital; $\mathrm{r}(241)=0.38, \mathrm{p}<0.001$. Whereas patients who had an ICU admission, stayed more than 11 days in the hospital than patients without ICU admission.

- Female gender was a significant factor shortened the hospital stay; $\mathrm{r}(241)=0.13, \mathrm{p}<0.03$, whereas females tended to stay about 2 days less than males.

- Patients age was a significant factor affecting the hospital stay; $r(241)=0.23, p<0.001$. The older patients tended to stay longer in the hospital, whereas patients older than 12.1 years tended to stay more than 3.7 days in the hospital.

- The nationality was a significant factor affecting the hospital LOS; $\mathrm{r}(241)=0.25, \mathrm{p}<0.001$. African nationalities (Sudan, Somali, Ethiopia and Chad) tended to stay longer in the hospital.

\section{Discussion}

King Abdulaziz University Hospital is a 600-bed institution. It is not a well-defined trauma centre due to the following; it does not accept trauma referrals, unable to provide care for every aspect of trauma from prevention through rehabilitation, or have a clear transfer agreement with a well-defined trauma centre ${ }^{[3]}$.

This report is a retrospective study. In comparison with another study from Norway ${ }^{[4]}$, the results of this study are comparable in the incidence of TBI (83.3 vs. 75$)$ but differ in the mean patient age (29 vs. 9.5 years). The results of this study, however, are in agreement with the Norwegian study in terms of the most prevalent mechanism of injury (falls); hence, falls in the paediatric age group are easier to prevent than in older age groups. A regional prevention program needs to be applied to this group to minimize the risk of disability ${ }^{[5]}$.

The total number of patients (258) examined in this study seems low; however, KAUH is not a trauma referral centre, and the sample represented admitted patients only. The incidence is $75 / 100000$, in 
comparison with Andelic et al. ${ }^{[4]}$, which had an incidence of 83.3/100 000. This difference can be explained by the limited population at risk in our study. There is also a geographical variation in the epidemiology of head injury with regard to the mechanism of injury, the mean age of patients ${ }^{[5-7]}$ and incidence rates ${ }^{[8-16]}$ (Table 3).

It seems that February and September are the months with the highest numbers of TBIs; it is speculated that these higher rates are due to school holiday time. An awareness program involving children and parents needs to be launched around this time each year ${ }^{[5]}$.

Table 3. Summary of selected articles with incidence rates for TBI.

\begin{tabular}{l|c|c|c}
\hline \multicolumn{1}{c|}{ Article } & Country & Number & $\begin{array}{c}\text { Incidence per } \\
\mathbf{1 0 0 , 0 0 0}\end{array}$ \\
\hline Rickets et al. $(2010)$ & Germany & 6783 & 332 \\
\hline Masson et al. $(2001)$ & France & 497 & 17.3 \\
\hline Styrke et al. $(2007)$ & Sweden & 449 & 354 \\
\hline Servadel et al. $(2002)$ & Italy & 2430 & 250 \\
\hline Andelic et al. $(2008)$ & Norway & 445 & 83.3 \\
\hline Bener et al. $(2010)$ & Qatar & 1919 & $4.2-4.9 / 10000$ \\
\hline Chiu et al. $(1997)$ & Taiwan & 58563 & 220 \\
\hline Meerhoff et al. $(1997)$ & Netherlands & 1933 & 88 \\
\hline Zhao et al. $(2000)$ & China & 246812 & 55.4 \\
\hline Corrigan et al. $(2010)$ & USA & Nationwide & 85 \\
\hline
\end{tabular}

The age distribution of patients shows that TBI is more common in younger generations $(82 \%)$ aged $<30$ years, which matches other TBI data ${ }^{[17-20]}$. However, our study showed a mean age of $9.5 \pm 4$ years, which is much younger than given in the literature.

The nationality is considered in this study to know the cultures at risk of TBI, so their languages are included in any prevention program.

The most common mechanism of injury is falling from a height, followed by motor vehicle collision, which matches the results of Andelic et $a l^{[4]}$. The usual clinical presentation is nausea and vomiting with confusion, which is not surprising, and is known from other studies $^{[21]}$. 
The most prevalent mode of transportation to the ER, by civil car, for most of the patients is related to two factors: poor trauma-handling education in the community and the hesitation of ambulance drivers to bring trauma patients to a non-trauma centre. Prehospital emergency medical care needs to be improved in order to improve the outcomes $^{[22]}$. As well the trauma clinical details documentation needs to be looked after by the physicians to improve the public awareness.

The most common type of injury was found to be concussion, followed by subdural hematoma, which is expected from the most common mechanism of injury of falling from a height.

The cost of TBI at KAUH seems high. Our calculation considered nursing care, imaging, ICU stay, blood investigation and surgeries. This cost is close to the one quoted by Sut and Memis ${ }^{[23]}$. The factors mentioned affecting the patients' LOS in the hospital is helpful in counseling the patients, their families and friends. As well they are important in health care planning and bed utilization. A similar article ${ }^{[24]}$ raises this issue with very close results in term of GCS, ethnicity and gender effect on the LOS. The current article demonstrates those factors effect on our population. The female gender has been a constant factor in short $\operatorname{LOS}^{[25]}$, this current study confirms this observation in the study population. The African nationalities tended to stay longer in the hospital because they tend to have worse injury, and may be poor socioeconomic status where they needs basic support that probably not available at their homes.

The key issue in preventing TBI in our sample is education of the community regarding safety measures, especially among construction workers and kids, such as the 'Think First' program proven to reduce the severity of $\mathrm{TBI}^{[26]}$. Additionally, a nationwide head injury prevention campaign should be initiated. A second issue is the need to categorize hospitals according to trauma care levels, and to establish a well-defined inter-hospital trauma referral and agreement system. The limitations of this study are the retrospective design, the inpatients single centre inclusion and the relative small number of cases. Nevertheless, this sample represents the community very well where there is a multicultural environment with approximate ratio of 
Saudi nationals to non-Saudis of 1:1. This study demonstrates some pattern of head injury on the academic centre sittings.

The recommendations that can be taken from this study are:

- To conduct a public head injury prevention awareness program.

- To classify the health care centres according to their trauma levels.

- To activate the trauma inter-hospital referral system.

- To educate the community regarding the proper trauma handling.

- To provide a social support to the high risk group.

\section{Conclusions}

Factors affecting the length of stay in an academic centre in western Saudi Arabia are admission GSC, the loss of consciousness, the presence of motor weakness, female gender, patients' age and nationality. A TBI comprehensive care program needs to be established.

\section{Acknowledgments}

The authors would like to thank Ms. Maha Daffa in medical records and Ms. Razan Mikwar in the IT department for their excellent assistance and effort in collecting the data for this article.

\section{Declaration of Interest}

The authors report no declaration of interest.

\section{References}

[1] Ansari S, Akhdar F, Mandoorah M, Moutaery K. Causes and effects of road traffic accidents in Saudi Arabia. Public Health 2000; 114(1): 37-39.

[2] Isam S, Al Ghamdi A. Analysis of injuries resulting from road traffic accidents in Riyadh district. King Saud Mag Eng Sci 1996; 8: 235-250.

[3] Centers for Disease Control and Prevention. Guidlines for field triage of injuried patients: recommendations of the National Expert Panel on field triage. MMWR 2009; 58(RR-1): 1-35. 
[4] Andelic N, Sigurdardottir S, Brunborg C, Roe C. Incidence of hospital-treated traumatic brain injury in the Oslo population. Neuroepidemiology 2008; 30(2): 120128.

[5] Durkin MS, Laraque D, Lubman I, Barlow B. Epidemiology and prevention of traffic injuries to urban children and adolescents. Pediatrics 1999; 103(6): e74.

[6] Tsai WC, Chiu WT, Chiou HY, Choy CS, Hung CC, Tsai SH. Pediatric traumatic brain injuries in Taiwan: an 8-year study. J Clinical Neuroscience 2004; 11(2): 126129.

[7] Murgio A, Fernandez Mila J, Manolio A, Maurel D, Ubeda C. Minor head injury at paediatric age in Argentina. J Neurosurgical Sci 1999; 43(1): 15-23.

[8] Rickels E, von Wild K, Wenzlaff P. Head injury in Germany: a population-based prospective study on epidemiology, causes, treatment and outcome of all degrees of head-injury severity in two distinct areas. Brain Inj 2010; 24(12): 1491-1504.

[9] Masson F, Thicoipe M, Aye P, Mokni T, Senjean P, Schmitt V, Dessalles PH, Cazaugade M, Labadens P; Aquitaine Group for Severe Brain Injuries Study. Epidemiology of severe brain injuries: a prospective population-based study. J Trauma 2001; 51(3): 481-489.

[10] Styrke J, Stålnacke BM, Sojka P. Traumatic brain injuries in a well-defined population: epidemiological aspects and severity. J Neurotrauma 2007; 24(9): 1425 1436.

[11] Tagliaferri F, Compagnone C, Korsic M, Servadei F, Kraus J. A systematic review of brain injury epidemiology in Europe. Acta Neurochir (Wien) 2006; 148(3): 255268.

[12] Bener A, Omar AO, Ahmad AE, Al-Mulla FH, Abdul Rahman YS. The pattern of traumatic brain injuries: a country undergoing rapid development. Brain Inj 2010; 24(2): 74-80.

[13] Chiu WT, Yeh KH, Li YC, Gan YH, Chen HY, Hung CC. Traumatic brain injury registry in Taiwan. Neurol Res 1997; 19(3): 261-264.

[14] Meerhoff SR, de Kruijk JR, Rutten J, Leffers P, Twijnstra A. [Incidence of traumatic head or brain injuries in catchment area of Academic Hospital Maastricht in 1997]. Ned Tijdschr Geneeskd 2000; 144(40): 1915-1918.

[15] Zhao YD, Wang W. Neurosurgical trauma in People's Republic of China. World J Surg 2001; 25(9): 1202-1204.

[16] Corrigan JD, Selassie AW, Orman JA. The epidemiology of traumatic brain injury. $J$ Head Trauma Rehabil 2010; 25(2): 72-80.

[17] Garcia-Molina A, Bernabeu Guitart M, Roig-Rovira T. [Traumatic brain injury and daily life: the role of executive function]. Psicothema 2010; 22(3): 430-435.

[18] Ogunrin OA, Adeyekun AA. Profile of post-traumatic epilepsy in Benin City, Nigeria. West Afr J Med 2010; 29(3): 153-157.

[19] Kosch Y, Browne S, King C, Fitzgerald J, Cameron I. Post-traumatic amnesia and its relationship to the functional outcome of people with severe traumatic brain injury. Brain Inj 2010; 24(3): 479-485. 
[20] Karasu A, Sabanci PA, Cansever T, Hepgül KT, Imer M, Dolaş I, Taviloğlu K. Epidemiological study in head injury patients. Ulus Travma Acil Cerrahi Derg 2009; 15(2): 159-163.

[21] Holsti M, Kadish HA, Sill BL, Firth SD, Nelson DS. Pediatric closed head injuries treated in an observation unit. Pediatr Emerg Care 2005; 21(10): 639-644.

[22] Klemen P, Grmec S. Effect of pre-hospital advanced life support with rapid sequence intubation on outcome of severe traumatic brain injury. Acta Anaesthesiol Scand 2006; 50(10): 1250-1254.

[23] Sut N, Memis D. Intensive care cost and survival analyses of traumatic brain injury. Ulus Travma Acil Cerrahi Derg 2010; 16(2): 149-154.

[24] Cuthbert JP, Corrigan JD, Harrison-Felix C, Coronado V, Dijkers MP, Heinemann AW, Whiteneck GG. Factors that predict acute hospitalization discharge disposition for adults with moderate to severe traumatic brain injury. Arch Phys Med Rehabil 2011; 92(5): 721-730.

[25] Slewa-Younan S, Green AM, Baguley IJ, Gurka JA, Marosszeky JE. Sex differences in injury severity and outcome measures after traumatic brain injury. Arch Phys Med Rehabil 2004; 85(3): 376-379.

[26] Salvarani CP, Colli BO, Carlotti Junior CG. Impact of a program for the prevention of traffic accidents in a Southern Brazilian city: a model for implementation in a developing country. Surg Neurol 2009; 72(1): 3-16. 


\section{نمط إصابة الدماغ في مستشفى الملك عبدالعزيز الجامعي}

\section{محمد بنقش، وأحمد الشريف'}

قسم الجراحة، شعبة جراحة المخ والأعصاب، و 'طبيب /متياز ، قسم الجراحة، شعبة جراحة المخ والأعصاب

كلية الطب، جامعة الملك عبدالعزبز

جلة - المدلكة العربية السعودية

المستخلص. تشكل إصابات الدماغ مشكلة في المجتمع قد تؤدي إلي الوفاة. الهدف من هذه الدراسة هو وصف نمط إصابة الدماغ في مستشفى الملك عبدالعزيز الجامعي وإيجاد العو امل الديمو غر افية و السريريّة التيّ يمكن أن تؤثر في طول الإقامة في المستشفى للناجيين من إصابة الدماغ. تمت هذه الدراسة بالطريقة الاستعاديّة في مستشفى الملك عبدا لعزيز

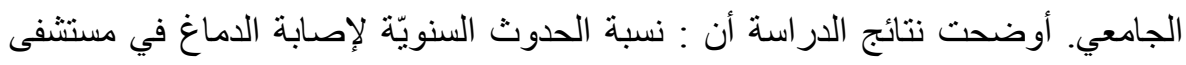

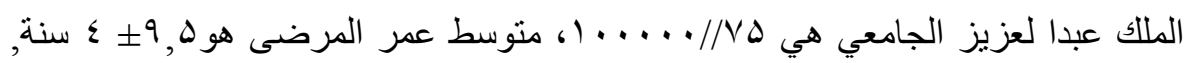

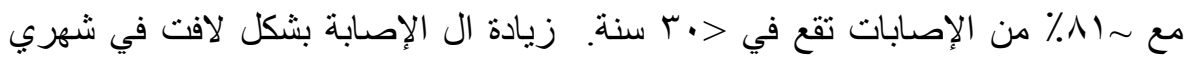

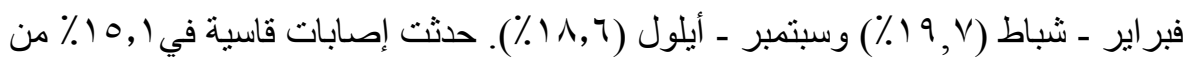

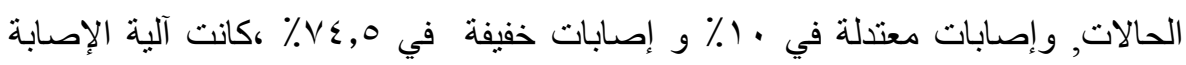

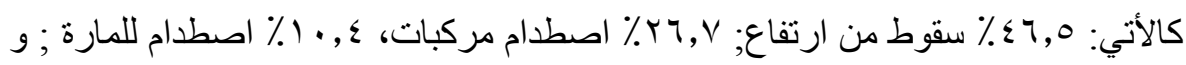
ع,. • ٪ ضحايا اعتداء. العوامل المؤثرة في طول الإقامة هي: هبوط مقياس غلاسكو

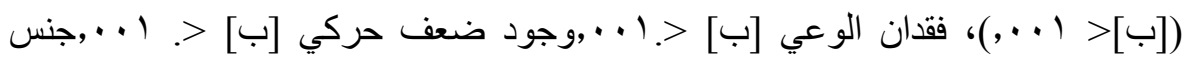

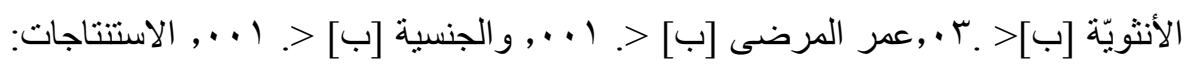
تتميز إصابات الدماغ في مستشفى الملك عبدا لعزيز الجامعي بانخفاض عمر المصابيين, آلية الإصابة في المقام الأول هي السقوط ونوع الإصابة هي الارتجاج. طول إقامة المرضى بمكن التنبؤ بها تقريبا على أسس المعطيات الديمو غر افية والسريريّة. 